\title{
Population biology and secondary production of the sandhopper Pseudorchestoidea brasiliensis (Amphipoda: Talitridae) at Prainha Beach, Brazil
}

\author{
Ricardo S. Cardoso ${ }^{1, *}$, Valéria G. Veloso ${ }^{1,2}$ \\ 'Departamento de Zoologia, Instituto de Biologia, Universidade Federal do Rio de Janeiro - CCS - Ilha do Fundão - \\ CEP 21941-570, Rio de Janeiro, RJ, Brazil \\ ${ }^{2}$ Departamento de Cièncias Naturais, Universidade do Rio de Janeiro - CCBS - R. Frei Caneca, no. 94 - $5^{\circ}$ Andar - \\ (Centro) CEP 22211-030, Rio de Janeiro, RJ, Brazil
}

\begin{abstract}
The population biology of Pseudorchestoidea brasiliensis (Dand, 1853) (Amphipoda: Talitridae) was studied by monthly sampling from June 1993 through May 1995 at Prainha Beach Brazil. Three transucts were established, each with 5 levels parallel to the waterline. From each level, 4 replicates were taken with a $0.04 \mathrm{~m}^{2}$ sampler. A stratified distribution was observed, with individuals 3 to $8 \mathrm{~mm}$ in length concentrated at the lower levels, while 9 to $12 \mathrm{~mm}$ individuals were distributed farther from the waterline. Highest population densities were observed in winter (August 1993 and July 1994) and summer (February 1994 and 1995). Ovigerous females and juveniles were observed during the entire sampling period, indicating continuous reproduction of the population. The sex ratio was 1.45 for females. Mean brood size was 2.8 eggs and mean egg volume was $0.04 \mathrm{~mm}^{3}$ The production of small eggs might be linked to small size at maturation of the females, which could increase the population growth rate. Growth and mortality rates were greater for males than females. Annual production was about $0.30 \mathrm{~g} \mathrm{AFDW} \mathrm{m}^{-2} \mathrm{yr}^{-1}$ and the $P / B$ ratio varjed from 2.16 to 2.3 , while life span varied between 12 and $21 \mathrm{mo}$.
\end{abstract}

KEY WORDS: Population biology - Secondary production Brazil Sandy beaches - Talitridae Pseudorchestoidea

\section{INTRODUCTION}

Among those organisms which are part of the macrofauna of exposed sandy beaches, the talitrid amphipods have received special attention because they are one of the faunal dominants (Macintyre 1963, McLachlan et al. 1981), and because they play an important ecological role as decomposers (Griffiths et al. 1983). Like other intertidal invertebrates, the sandhoppers of sandy beaches occupy various intertidal or supralittoral habitats and can differ in behavior and population characteristics, including reproductive patterns (Marsden 1991). The talitrids are herbivorous or detritivorous and are generally associated with kelp

·E-mail: rcardoso@br.homeshopping.com br and wrack cast ashore by waves and tides (Behbehani \& Croker 1982, Marsden 1991), feeding on this plant material and debris and migrating up and down the shore in search of food.

Most studies on the Talitridae family are concerned with reproductive biology (Morino 1978, Williams 1978, Wildish 1979, 1982). Marsden (1991), studying Talorchestia quoyana, observed that the reproductive strategies of producing several broods, increasing parental care and releasing large hatchlings into the optimal habitat are important for survival in the intertidal sand beach habitat, which has been regarded as the most physically harsh of all marine environments. In most cases, juveniles present a faster growth rate than adults (Wildish 1972, Williams 1978). Marsden (1989) associated the high growth rate of juveniles with their continuous feeding. Van Senus \& McLachlan (1986) 
observed a rapid growth rate and a low mortality for Talorchestia capensis, while Wildish (1972) suggests that a slow growth rate would have been a step towards the evolution of primitive terrestrial Orchestia.

The genus Orchestoidea has been studied by only a few authors: Bowers (1964) described the clumped pattern, nocturnal activity period and reproductive cycle of $O$. californiana and $O$. corniculata. Craig (1971, $1973 a, b)$ observed the behavioral activity, spatial distribution along shore and lunar orientation of $O$. corniculata, while Duarte (1974) investigated the feeding behavior of $O$. tuberculata on the Chilean coast.

The present study is the first to examine the distribution pattern, population and reproductive biology, production and turnover of Pseudorchestoidea brasiliensis (Dana, 1853), a species which until recently was classified in the genus Orchestoidea (E. L. Bousfield 1982 pers comm.). $P$ brasiliensis is a common and abundant species in the reflective beaches of Rio de Janeiro State.

\section{MATERIALS AND METHODS}

Study area and sampling. Monthly samples were taken from June 1993 through May 1995 at Prainha Beach, Recreio dos Bandeirantes, State of Rio de Janeiro, Brazil $\left(23^{\circ} 05^{\prime} \mathrm{S}, 43^{\circ} 25^{\prime} \mathrm{W}\right)$.

The collections were made during spring tides on 3 transects, each divided into 5 strata parallel to the waterline. Strata locations were as follows: Stratum 1 -below the swash line; Strata 2, 3 and 4-in the lower, middle and upper midlittoral, respectively; Stratum 5-above the drift line (supralittoral). The width of the beach at the time of collection varied between 43 and $65 \mathrm{~m}$. From each level, 4 replicates were taken using a $0.04 \mathrm{~m}^{2}$ metal sampler up to a depth of $25 \mathrm{~cm}$.

This beach was characterized by Veloso et al. (in press) as semi-exposed using the McLachlan (1980) ranking system, and as a reflective type in the classification proposed by Short \& Wright (1983) and Masselink \& Short (1993). The mean grain size is $0.43 \mathrm{~mm}$ (medium sand) and the intertidal slope varies from $1 / 5.29$ to $1 / 17.82$.

Laboratory procedures. The material was sorted using a stereomicroscope and preserved in $10 \%$ formalin. Each individual was sexed using the stereomicroscope and sorted into: (a) males, with a developed second gnathopod; (b) females, with oostegites and without a developed second gnathopod; (c) juveniles, lacking both oostegites and a developed second gnathopod; and (d) ovigerous females, with both oostegites and eggs. The individuals were then measured from the beginning of the cephalon to the end of the telson and grouped into $1 \mathrm{~mm}$ size classes. Eggs of ovigerous females were counted and measured. Afterwards the individuals were dried at $70^{\circ} \mathrm{C}$ for $24 \mathrm{~h}$, weighed, ashed in a muffle furnace for 4 h at $600^{\circ} \mathrm{C}$ and then reweighted.

The 2 sampling years June 1993 to May 1994 and June 1994 to May 1995 were studied separately in order to analyze the temporal variation of population parameters (growth, mortality and secondary produc tion). Growth and mortality were estimated for males and females separately. Juveniles were divided into $50 \%$ males and $50 \%$ females to analyze growth and mortality rates.

A $\chi^{2}$ test was used to test the proportion of males to females, as well as to verify the distribution of length classes and sex categories in the sampling strata. Twoway ANOVA and Duncan's multiple range test were performed to analyse the distribution of length classes and sex categories in the sampling strata. Stratum 1 was excluded from this analysis owing to the absence of any specimens in it during the whole sampling period.

Reproduction. The monthly proportion of males to females (sex ratio) were tested by a $\chi^{2}$ test.

Fecundity was determined by correlating the length of the 597 ovate females collected with the mean number of eggs per brood. The egg volume, estimated from the egg diameter of 450 eggs, was calculated by: $V=4 / 3 \pi r^{3}$, where $r$ is the radius of the eggs (Wildish 1982).

Growth. Growth parameters were estimated using the ELEFAN I routine of the computer program Compleat ELEFAN (Version 1.10) which adjusts the von Bertalanffy curve, modified for seasonal oscillation in growth (Pauly \& Gaschutz 1979), using the equation:

$$
L_{t}=L_{\infty}\left\{1-\mathrm{e}^{K\left(\left(t-t_{0}\right)+\frac{C}{2 \pi} \sin \mid 2 \pi\left(t-t_{5}\right)\right)}\right\}
$$

where $L_{l}$ is length at time $t(\mathrm{~mm}) ; L_{0}$ is asymptotic length (mm); $K$ is von Bertalanffy's growth constant; $C$ is a constant for the amplitude of seasonal oscillation of growth; $t_{0}$ is age at zero length; and $t_{\mathrm{s}}$ is the initial point of seasonal oscillation in relation to $t=0$. The graphical representation of this equation produces a curve of which the agreement is represented by $R n$, which is analogous to the parameter $r^{2}$ in correlation analysis (Gayanilo et al. 1989). The modified Wetherall method (Pauly 1986) was used to obtain preliminary estimates of $L$, for the ELEFAN II routine, thus reducing the iterative process of calculating the growth parameters (Rufino 1991. Urban \& Campos 1994). Life span was estimated considering $T_{\text {max }}$ as the length at which $99 \%$ of the population was represented.

Mortality. Total mortality $(Z)$ was calculated based on the length-converted catch curve of the ELEFAN II routine, using the negative exponential model: $N_{i} / \Delta t_{l}=$ 
$N_{0} e^{-Z t_{1}}$, where $N_{0}$ is the number of individuals at time zero, $N_{1}$ is the number of individuals of length class $i$, $\Delta t_{t}$ is the time necessary for growth within length class $i$ and $t_{t}$ is the age of mean length of length class $i$. In all calculations of $Z$, for the length-converted catch curve, only those points located between the maximum and next last value of the curve were used (Sparre et al. 1989). The annual finite mortality rate $(A)$ was obtained from the expression: $A=1-\mathrm{e}^{-2}$ according to Ricker (1975)

Secondary production. Production was estimated by 3 methods: (1) Modified Hynes method or 'sizefrequency' (Hynes \& Coleman 1968, Hamilton 1969, Benke 1979, Menzie 1980), which is based on survival and increase in mean weight per generation, expressed as follows: $P=\sum\left(N_{j}-N_{j+1}\right) \cdot\left(W_{t} W_{t+1}\right)^{1 / 2}$, where $N_{j}$ is the number of individuals that grow to the mean size of the size class during $1 / i$ of the year (Hamilton 1969); and $\left(W_{t} W_{t+1}\right)^{1 / 2}$ is the mean geometric weight between 2 successive length classes. $N_{j}=i \cdot N \cdot 365 / C P I \cdot P_{\mathrm{e}} / P_{\mathrm{a}}$, where $i$ is the number of length classes, $N$ is the mean number of individuals in the size class, $C P I$ is the time from hatching to death of the largest size class, $P_{\mathrm{e}}$ is the estimated proportion of the life cycle spent in a particular length class $(=1 / i)$, and $P_{\mathrm{a}}$ is the actual proportion of the life cycle spent in a particular length class.

(2) Method of production for stocks with recruitment age classes not separable-Crisp's method 3A. In these calculations it is necessary to measure growth or mortality rates as a function of size and season and to carry out a summation throughout the year for each size class (Crisp 1984). The production is given by the equation: $P=\sum \sum f_{1} \cdot G_{1} \cdot w_{i} \cdot \Delta t$, where $f_{i}$ is the number of individuals of this size class existing in the population during the period $\Delta t, G_{1}$ is the weight-specific growth rate of size class $i, w_{i}$ is the mean weight of the size class and $\Delta t$ is the interval of time. $G_{i}$ can be obtained by $G_{i}=\ln w_{i+1}-\ln w_{i} / \Delta t_{(i+1-1)}$.

(3) Allen's (1971) method for populations whose mortality is expressed by the exponential model, and growth by Bertalanffy's model. In these cases, the ratio between production and biomass equals the mortality rate: $P / B=Z$ and thus $P=Z \cdot B$. The mortality rate $(Z)$ used by the Allen method was obtained by the mean of the rates $(Z)$ estimated by Wetherall's method and by the length-converted catch curve.

The relationship between length and dry weight was estimated by linear regression analysis, with the data converted to logarithms in the equation: $\log W=$ $\log a+b \log L$, where $W$ is the monthly mean ash-free dry weight per individual (mg), $L$ is the length of the size class (mm) and $a$ and $b$ are constants. The F-test was used to test the significance of the correlation coefficient.

\section{RESULTS}

\section{Population structure}

The population of Pseudorchestoidea brasiliensis showed the highest densities in the winter (August 1993 and July 1994) and late summer (February 1994 and 1995). The lowest densities were recorded in spring 1993 and 1994, and in autumn 1995 (Fig. 1). The densities of males and non-ovigerous females were similar during both years sampled (Fig. 2). Juvenile individuals ( 3 and $4 \mathrm{~mm}$ ) showed 3 density peaks: at the beginning of spring (September 1993), beginning of winter (June 1994) and summer (February 1995). Low densities were observed in spring (October 1993

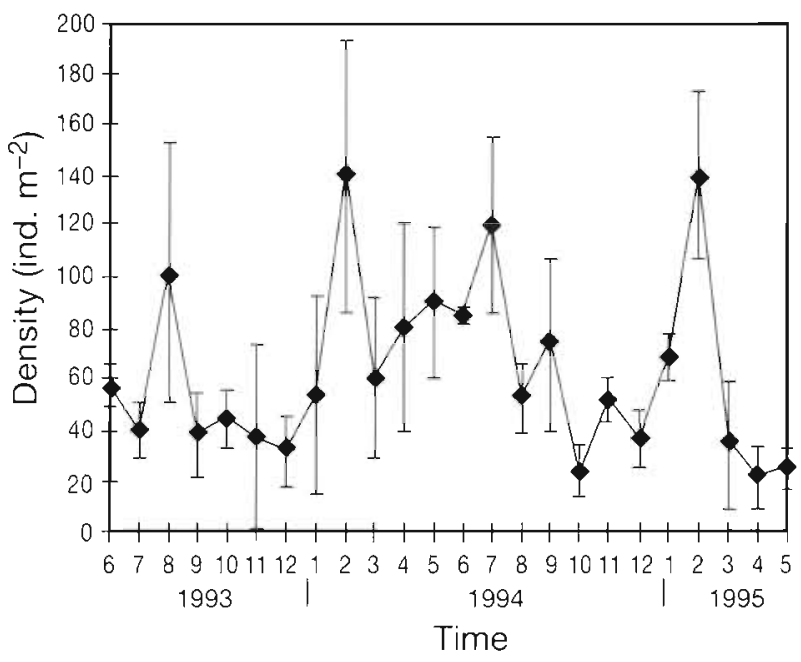

Fig. 1. Pseudorchestoidea brasiliensis. Population density for the period June 1993 to May 1995. Vertical bars represent standard deviation

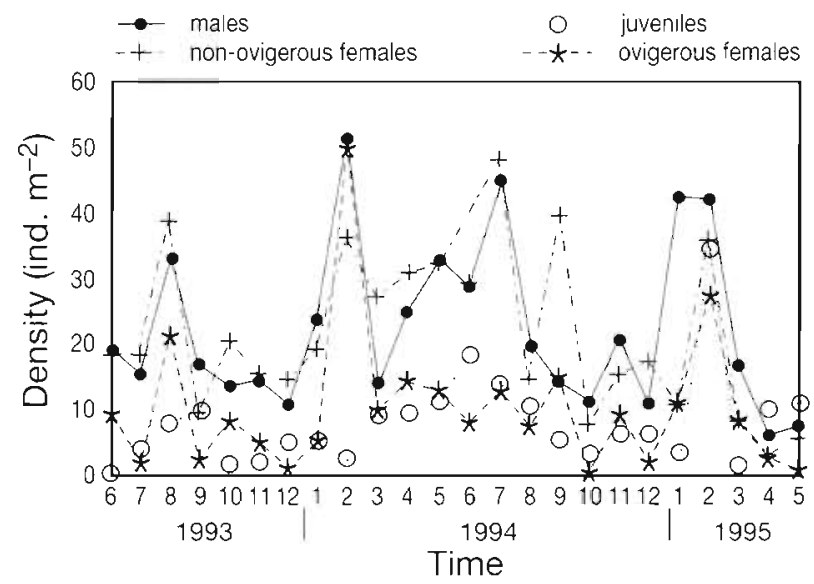

Fig. 2. Pseudorchestoidea brasiliensis. Population density of males, non-ovigerous females, ovigerous females and juveniles for the period June 1993 to May 1995 
and 1994, November 1993), summer (February 1994) and autumn (March 1995) (Fig 2). Ovigerous females were captured during all collections, the highest densities being observed during winter (August 1993 and September 1994) and late summer (February 1994 and 1995), while low densities were recorded in spring (September 1993 and October 1994), early summer (December 1993 and 1994) and late autumn (April and May 1995) (Fig. 2). The sex ratio between males and non-ovigerous females was $1: 1$ ( $p>0.05)$, while the sex ratio between males and (ovigerous and nonovigerous) females was $1: 1.5(\mathrm{p}<0.05)$. The greatest deviations in the sex ratio occurred in October 1993 and March and September 1994 (Fig. 3).

The high standard deviations in Fig. 1 suggest a clumped distribution of individuals mainly on Stratum 2, located in the lower midlittoral (Table $1 \mathrm{~b}$ ).

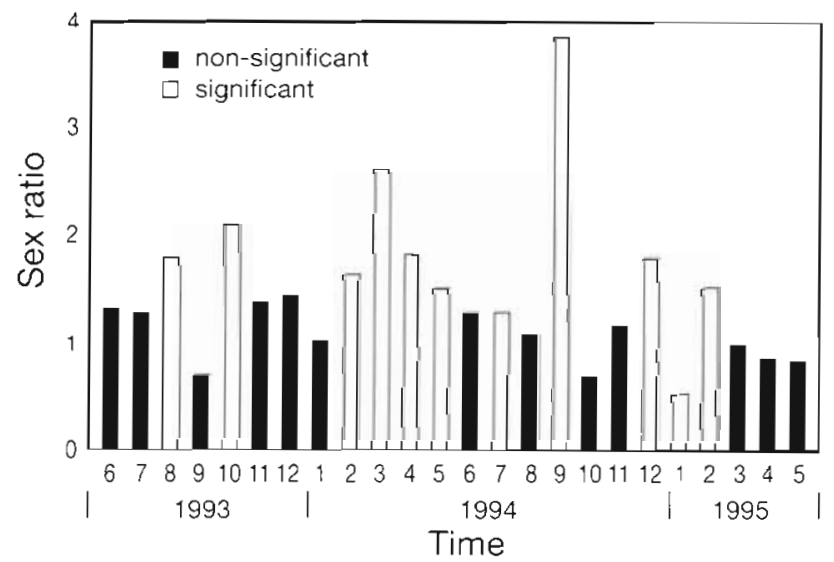

Fig. 3. Pseudorchestoidea brasiliensis. Sex ratio during the period June 1993 to May 1995

Table 1 (a) Analysis of variance: 2-way ANOVA. Relation between sampling strata and sex categones of Pseudorchestoidea brasiliensis. $\mathrm{df}=$ degrees of freedom. $\mathrm{p}=$ probability level. (b) Results of Duncan's multiple range test analysis undertaken as a posteriori test of multiple compansons to indicate statistical significance

\begin{tabular}{|lrrrrr|}
\hline (a) & df & $\begin{array}{c}\text { Sum of } \\
\text { squares }\end{array}$ & $\begin{array}{c}\text { Mean } \\
\text { squares }\end{array}$ & $F$ & $p$ \\
\hline Sampling strata & 3 & 10080.79 & 3360.26 & 26.91 & 0.00 \\
Sexcategories & 3 & 4421.97 & 1473.99 & 61.34 & 0.00 \\
Interaction & 9 & 856.83 & 95.20 & 1.74 & 0.08 \\
Residual & 368 & 20157.79 & 54.77 & & \\
Total & 383 & 35517.38 & & & \\
(b) & & \multicolumn{5}{c}{ Sampling stratum } & \\
& & 2 & 3 & 4 & 5 \\
\hline Mean abundance & 15.97 & 11.70 & 7.18 & 2.28 \\
Non-significance & - & - & - & - \\
\hline
\end{tabular}

There was no stratification by sex, but all. sex categories preferred Stratum 2 (lower part of the midlittoral) (Fig. 4). This was confirmed in a 2-way ANOVA and by Duncan's multiple range test (Table $1 \mathrm{a}, \mathrm{b}$ ). Significant interaction effects were observed between sampling strata and length classes. There is a significant dependence between length classes and spatial location of the individuals on the beach (Table 2). The 3 to $7 \mathrm{~mm}$ length classes were preferentially distributed at Stratum 2; $8 \mathrm{~mm}$ individuals were found at Stratum 2 as much as at Stratum 3, while $9 \mathrm{~mm}$ individuals were distributed over the whole midlittoral (Strata 2, 3 and 4), and 10 to $12 \mathrm{~mm}$ individuals occurred in all strata (Fig. 5).

\section{Reproduction}

A linear relationship between the mean number of eggs per brood $(Y)$ and the body length of ovigerous females $(X)$ was found (Fig.6). The highest frequencies of ovigerous females were found at lengths 8 and $9 \mathrm{~mm}$, with a mean length of $8.5 \mathrm{~mm}$. The mean number of eggs per clutch was 2.8, while the mean egg diameter was $0.42 \mathrm{~mm}$, corresponding to a volume of $0.04 \mathrm{~mm}^{3}$ per egg.

\section{Growth}

The $L \approx$ values determined by the Wetherall method were used as preliminary values for adjusting the growth curves by the ELEFAN I routine (Table 3 ). The males had higher growth rates as compared to females in both years (Table 3 ). The values of parameter $C$ (degree of seasonal variation) showed no apparent

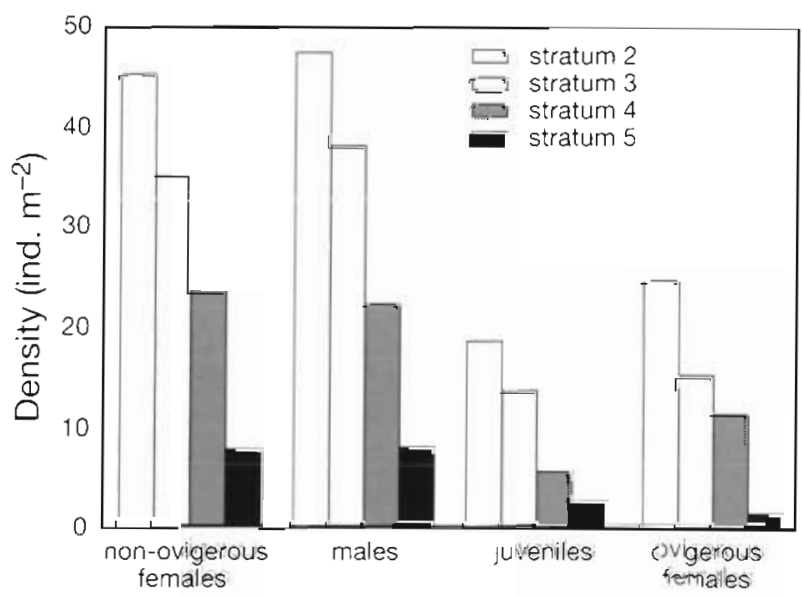

Fig. 4. Pseudorchestoidea braslliensis. Spatial variability of population density of males, non-ovigerous females, ovigerous females and juveniles along the sampling strata 
Table 2. Analysis of variance: 2-way AvOVA. Relation between sampling strata and length classes of Pseudorchestordea brasiliensis. $\mathrm{df}=$ degrees of freedom. $\mathrm{p}=$ probability level

\begin{tabular}{|lrrrrr|}
\hline & dt & $\begin{array}{c}\text { Sum of } \\
\text { squares }\end{array}$ & $\begin{array}{c}\text { Mean } \\
\text { squares }\end{array}$ & $F$ & $p$ \\
\hline Sampling strata & 3 & 2363.14 & 787.71 & 59.53 & 0.00 \\
Length classes & 9 & 6699.80 & 744.42 & 56.25 & 0.00 \\
Interaction & 27 & 1793.76 & 66.44 & 5.02 & 0.00 \\
Residual & 920 & 12174.04 & 13.23 & & \\
Total & 959 & 23030.75 & & & \\
\hline
\end{tabular}

variation between both sexes and years and were always between 0.9 and 1.0 , indicating a strong variation in growth. Values of WP (point of lowest growth rate during the year) differed between years and between sexes; however, males and females of the second sampling year showed close WP values (September) (Fig $7 \mathrm{a}, \mathrm{b}$ ). Life span of females was greater than that of males during the first year, being a function of the lower growth rates of the females. This did not occur during the second sampling year, because of the smaller difference between growth rates of males and females and the lower $T_{\text {max }}$ determined for the females.

\section{Mortality}

Mortality rates of males showed no differences when both sampling years were compared; also, no differences were demonstrated between mortality rates of males and females in the second year However, the males showed higher mortality than females in the first sampling year Note also that the female mortality rate was significantly higher in the second year, based on both estimation methods used (Table 4). The annual finite mortality rate $(A)$ of the males was 0.93 and $0.95 \mathrm{yr}^{-1}$, respectively, for the first and second years, while that of the females was 0.78 and $0.93 \mathrm{yI}^{-1}$. respectively.

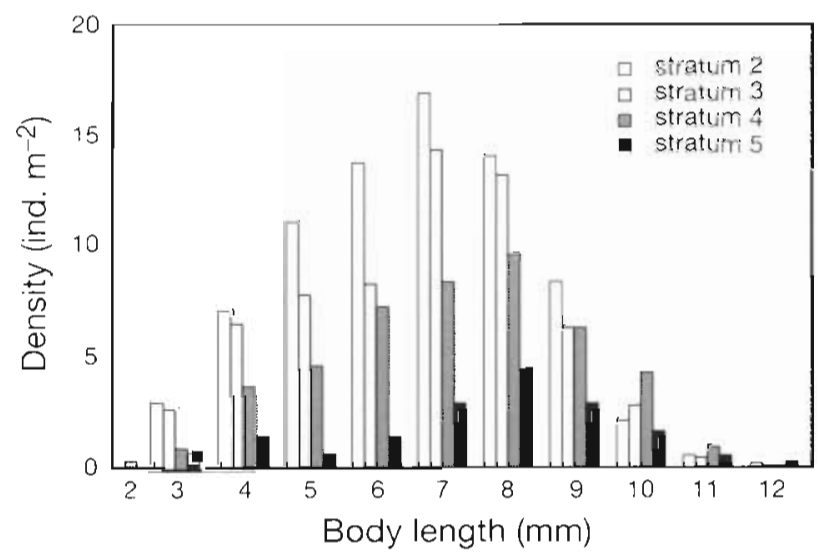

Fig. 5. Pseudorchestoidea brasiliensis. Spatial variability of population density in function of body length along the sampling strata

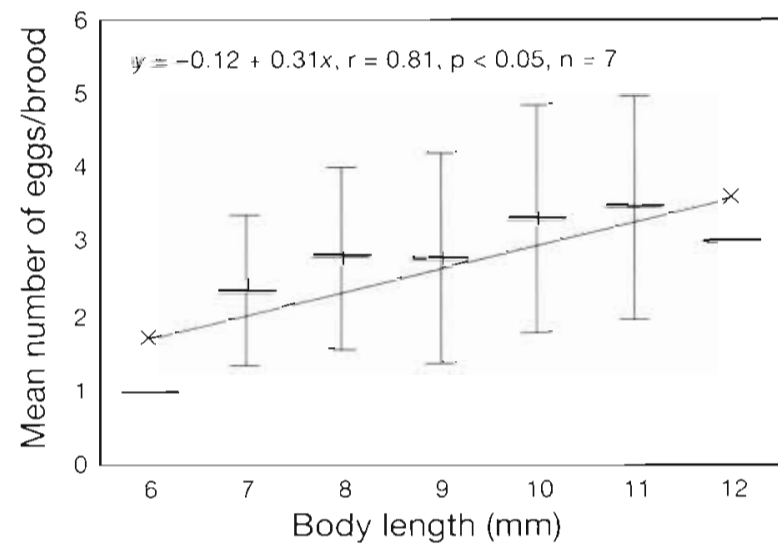

Fig. 6. Pseudorchestoidea brasiliensis. Relation between the mean number of eggs per brood and female body length in each size class. Vertical bars represent standard deviation

First and last size classes have only 1 specimen

\section{Secondary productivity}

The regression equation between mean weight and length classes for the total population of Pseudorchestoidea brasiliensis is expressed as: $\log$ AFDW $=-2.129$ $+2.727 \log ($ length $) ; n=214$ and $r=0.97(p<0.05)$

Table 3. Pseudorchestoidea brasiliensis. Von Bertalanffy growth function (VBGF) parameters: $L \cdots$ Wetherall and $L \cdots$ ELEFAN $=$ asymptotic length $(\mathrm{mm})$ determined by the modified Wetherall method and ELEFAN I routine, respectively; $K=$ von Bertalanffy's growth constant; $C=$ constant for the amplitude of seasonal oscillation of growth; $W P=$ point of lowest growth rate in the year; $R n=$ agreement of the estimated observed growth rates. $T_{\text {max }}$ : length (mun) at which $99 \%$ of the populatıon was represented and life span estimated for sex categories during the periods

\begin{tabular}{|lcccccccc|}
\hline Sex-period & $L_{\text {mwertherall }}$ & $L_{\text {meletan }}$ & $K$ & $C$ & WP & Rn & $T_{\text {max }}$ & Life span (mo) \\
\hline Females-93/94 & 12.50 & 12.50 & 0.90 & 0.9 & 0.5 May & 0.466 & 9.95 & 21.3 \\
Males-93/94 & 13.39 & 13.40 & 1.36 & 0.9 & 0.2 Mar & 0.501 & 10.75 & 14.4 \\
Females-94/95 & 12.37 & 13.41 & 1.41 & 1.0 & 0.8 Sep & 0.500 & 9.95 & 11.5 \\
Males-94/95 & 13.38 & 13.38 & 1.54 & 1.0 & 0.75 Sep & 0.445 & 10.60 & 12 \\
\hline
\end{tabular}




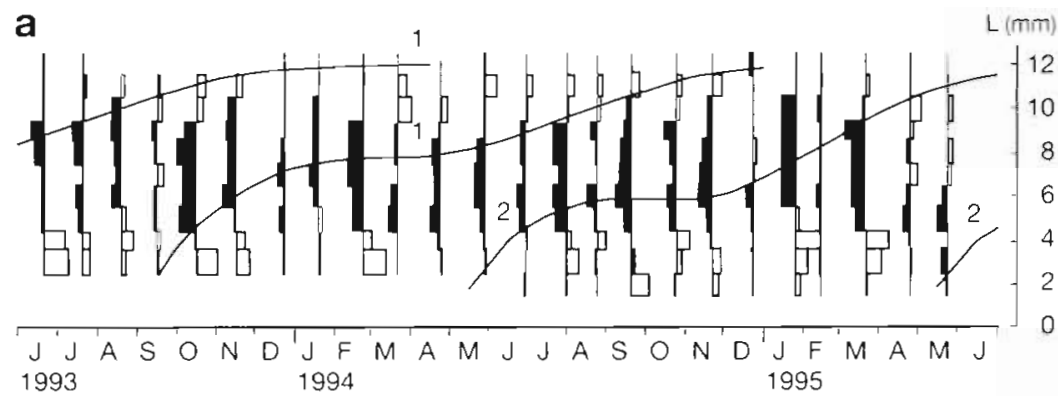

b

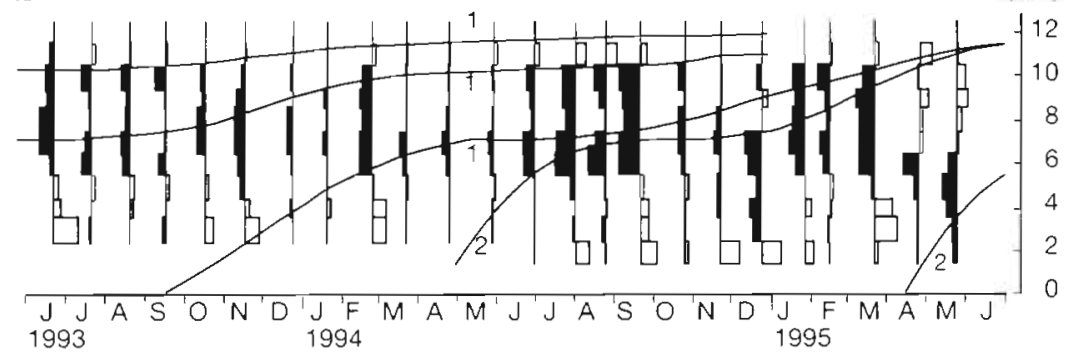

Fig. 7. Pseudorchestoidea brasiliensis. Growth curve of (a) males and (b) females estimated by ELEFAN program from 'restructured' length-frequency data set for the period June 1993 to May 1995. 1: June 1993 to May 1994; 2: June 1994 to May 1995

Mean biomass was $0.13 \mathrm{~g} \mathrm{AFDW} \mathrm{m}^{-2}$ for the first and second year. Similar production values were found using the different methods in both years (Table 5). The ratios between production and biomass $(P / B)$ using Crisp's and Hynes' methods, respectively, were 2.30 and 2.16 for the first year and 2.21 and 2.26 for the second year.

Table 4. Pseudorchestoidea brasilhensis. $Z$ values (mortalitu) estimated with the length-converted catch curve method and modified Wetherall method, for sex categories during the periods. $C I$; confidence interval of $Z$

\begin{tabular}{lcc}
\hline Sex-period & $Z_{\text {Wetherall }}$ & $Z_{\text {length.converted cotch curve }}(C I)$ \\
\hline Males-93/94 & 3.661 & $2.664(1.738)$ \\
Males-94/95 & 4.039 & $2.920(1.874)$ \\
Females-93/94 & 1.729 & $1.501(1.033)$ \\
Females-94/95 & 2.795 & $2.666(0.061)$ \\
\hline
\end{tabular}

Table 5. Pseudorchestoidea brasihensis. Secondary production in $\mathrm{g}$ A.FDW $\mathrm{m}^{-2} \mathrm{yr}^{-1}$ determined by 3 methods: modified

Hynes method. Crisp's method $3 \mathrm{~A}$ and the Allen method

\begin{tabular}{|lcc|}
\hline Methods & $\begin{array}{c}\text { June 1993 } \\
\text { to May 1994 }\end{array}$ & $\begin{array}{r}\text { June 1994 } \\
\text { to May 1995 }\end{array}$ \\
\hline Modified Hynes & 0.28 & 0.29 \\
Crusp (3A) & 0.30 & 0.28 \\
Allen & 0.33 & 0.36 \\
\hline
\end{tabular}

\section{DISCUSSION}

Fluctuations in population density, indicating periods of intense reproduction, are frequent in talitrids. Marsden (1991) observed higher densities of Talorchestia quoyana in summer (February) and late winter (September), a pattern similar to that observed for Pseudorchestoided brasiliensis.

Continuous reproduction was observed in Talorchestia capensis by Van Senus (1988) and in the gammarid Echinogammarus marinus (Marques \& Nogueira 1991), while seasonal reproduction was demonstrated by Marsden (1991) for Talorchestia quoyana and by Williams (1978) for Talitrus saltator. In Rio de Janeiro State, the continuous reproduction of Pseudorchestoidea brasiliensis was characterized by the presence of juveniles and ovigerous females during the entire year, in spite of periods of greater reproductive activity. The peaks of ovigerous females and juveniles were not coincident because of the time interval needed for the embryonic development of the eggs. The high densities of ovigerous females in February (late summer) and August (early winter) observed for $P$. brasiliensis were similar to those obtained for $T$. capensis (Van Senus 1988).

Pseudorchestoidea brasiliensis presents greater abundance in the lower midlittoral. Aggregation at Stratum 2 could be related to sediment moisture (Williams 1983), although this was not experimentally tested. Bowers (1964) and Behbehani \& Croker (1982) related clumped distribution of Orchestoidea corniculata and Orchestia platensis to algae location on the debris line.

Pseudorchestoidea brasiliensis showed the same stratified distribution pattern observed for Orchestoidea corniculata by Bowers (1964) and Craig (1973b) The location of the small individuals on the lower part of the midlittoral and the larger individuals preferentially on the upper part is probably related to their capacity to resist desiccation. There was no stratification of individuals in relation to sex.

The sex ratio of $1: 1$ was observed for Orchestia mediterranea (Wildish 1970); however, Williams (1978), working with Talitrus saltator, and Van Senus (1988), with Talorchestia capensis, both verified that the populations of females were greater than those of males, $1: 1.45$ and 1:1.33, respectively. In Pseudorchestoidea brasiliensis, females were 1.54 times more abundant 
than males. In the genus Ampelisca the deviation of the sex ratio toward females has usually been explained by the drastic decline in numbers of males which undergo ecdysis, copulate and then die (Klein et al. 1975, Hastings 1981, Carrasco \& Arcos 1984). In $P$. brasiliensis this has not yet been verified. Another proposal to explain the higher number of females in the population is that their life span is greater than that of the males and they remain longer in the population.

Van Senus (1988) observed a higher proportion of males after the peaks of ovigerous females independent of the season of the year. This would be due to a higher growth rate of juvenile males which may enter the population before the juvenile females, causing an increase in the proportion of males. In Pseudorchestoidea brasiliensis the periods in which higher proportions of males were present occurred only 1 or 2 mo after the peaks of ovigerous females in the winter.

The low fecundity observed for Pseudorchestoidea brasiliensis corroborates the statement of Marsden (1991) that the fecundity of sand-dwelling animals is lower compared to the supralittoral Orchestia species (Wildish 1979) and to gammarids of temperate waters (Steele \& Steele 1975). Gammarids show a direct relationship between body length and number of eggs per brood; however, this is less evident in beach sandhoppers. Brood size is strongly dependent on female length in Talitrus saltator (Williams 1978) and Talorchestia capensis (Van Senus 1988). However, in Talorchestia quoyana (Marsden 1991) and Platorchestia platensis (Morino 1978) this relationship is more variable, being similar to that found for $P$. brasiliensis (Fig. 6).

Factors such as temperature, humidity, season of the year, photo-period, nutritional level and geographical location can affect the production and mortality of broods, as well as the number and volume of eggs of talitrids (Morino 1978, Steele 1981, Williams 1985, Van Senus 1988). Marsden (1991) suggested that the low fecundity of Talorchestia quoyana may be compensated for by the production of larger eggs and by a low brood mortality, but the mean egg volume observed for Pseudorchestoidea brasiliensis does not support this. The mean diameter of the eggs of $P$. brasiliensis is small $(0.42 \mathrm{~mm})$ compared to those of other talitrids [ $T$ quoyana: $1.39 \mathrm{~mm}$ (Marsden 1991); Talitrus saltator. $\sim 0.88 \mathrm{~mm}$ (Williams 1978); Platorchestia platensis: $0.65 \mathrm{~mm}$ (Morino 1978); Orchestia mediterranea and o. mediterranea aestuarensis: $0.72 \mathrm{~mm}$, Orchestia cavimana: $0.69 \mathrm{~mm}$ and Orchestia remyi roffensis: $0.62 \mathrm{~mm}$ (Wildish 1979)]. Another hypothesis to explain the low fecundity of intertidal amphipods is their higher survival rate compared to species with a high fecundity (Marsden 1991); this is contradicted by the high mortality rates recorded for $P$. brasiliensis in comparison to other amphipods. The reproductive strategy of $P$. brasiliensis appears to fit other species for which the production of small eggs is related to decrease in the maturation size of females, which in turn allows the production of more than 1 brood, therefore increasing the number of generations and consequently increasing the intrinsic growth rate of the population (Steele \& Steele 1975). Such a hypothesis is likely to be correct for $P$. brasiliensis, as the smallest ovigerous female had a length of only $5 \mathrm{~mm}$.

The lower growth rates of females in relation to males must be related to a greater investment of energy in reproduction (production and maintenance of eggs and embryos), since the females do not undergo ecdysis during the period of incubation, making it difficult for them to continue to grow at the same rate as males. The lower life span determined for females of Pseudorchestoidea brasiliensis for the second in comparison to the first year can be explained by the combination of higher growth rate with a low $T_{\max }$ recorded for them in the second period. Life span differs within and among species of talitrids (Table 6); these differences can be related to different cohorts growing during different seasons of the year, to differences in growth rates among sex categories and to different geographical regions and environmental conditions, or even to different methods of estimation.

Table 6. Comparison of life span of several talitrids from different localities

\begin{tabular}{|c|c|c|c|c|}
\hline Species & Life span (mo) & Zonation & Geographical location & Source \\
\hline Pseudorchestoidea brasiliensis & $\begin{array}{r}21 \text { (female) and } 14 \text { (male) - 93/94 } \\
11.5 \text { (female) and } 12 \text { (male) - 94/95 }\end{array}$ & Midlittoral & $23^{\circ} 05^{\prime} \mathrm{S}, 43^{\circ} 25^{\prime} \mathrm{W}$ & This study \\
\hline Talorchestia capensis & 18 (cohort 1) and 24 (cohort 2) & Supralittora] & $33^{\circ} 43^{\prime} \mathrm{S}, 25^{\circ} 50^{\prime} \mathrm{E}$ & $\begin{array}{l}\text { Van Senus \& } \\
\text { McLachlan (1986) }\end{array}$ \\
\hline Talorchestia quoyana & 13 & Supralittoral & $45^{\circ} \mathrm{S}, 172^{\circ} \mathrm{E}$ & Marsden (1991) \\
\hline Talitrus saltator & 18 (female) and 21 (male) & Supralittoral & $54^{\circ} \mathrm{N}, 4^{\circ} \mathrm{W}$ & Williams (1978) \\
\hline Talorchestia margaritae & 3 & Supralittoral & $10^{\circ} \mathrm{N}, 64^{\circ} \mathrm{W}$ & Venables (1981) \\
\hline Orchestia remyi roffensis & 12 to 18 & Supralittoral & $57^{\circ} \mathrm{N}, 2^{\circ} \mathrm{W}$ & Wildish (1972) \\
\hline Orchestia platensis & $4-5($ cohort 1$)$ and $8-12$ (cohort 2$)$ & Supralittoral & $43^{\circ} 08^{\prime} \mathrm{N}, 70^{\circ} 37^{\prime} \mathrm{W}$ & $\begin{array}{l}\text { Behbehani \& } \\
\text { Croker }(1982)\end{array}$ \\
\hline
\end{tabular}


Annual mortality rates observed for males and females of Pseudorchestoidea brasiliensis are higher when compared to the mortalities of 0.22 and $0.16 y$ for the sandhopper Talorchestia capensis (Van Senus \& Mclachlan 1986) and of 0.20 and $0.05 \mathrm{yr}^{-1}$ for the freshwater hyalid Parhyale basrensis (Ali \& Salman 1987). These differences may be caused by: (1) latitude [tropical regions show higher mortality rates compared to temperate regions (Ansell et al. 1978)]; (2) the ecosystems the low mortality recorded for $T$. capensis may have been related to low predation on the beach of Sundays Rivers, South Africa (Van Senus \& McLachlan (1986)]; or (3) the methods to estimate mortality [Ali \& Salman (1987) demonstrated an underestimation of the mortality rate of Parhyale basrensis].

Knowing that these parameters influence the catch curve pattern, we may conclude that the lower mortality of females recorded for the first sampling year may be related to the lower growth rate and to the low $L$ recorded at that time.

The high production of Pseudorchestoidea brasiliensis that was estimated accounts for a large percentage of the overall production of the local macrofaunal community. The great abundance of $P$. brasiliensis, together with Excirolana braziliensis (detritivorous isopod), shows the importance of the detritus food web, as P. brasiliensis and E. braziliensis comprise about $40 \%$ of all individuals from the macrofaunal community (Veloso et al. in press).

The various methods used to estimate the secondary production of Pseudorchestoidea brasiliensis gave similar results, varying from 0.28 to $0.36 \mathrm{~g} \mathrm{AFDW} \mathrm{m}^{-2} \mathrm{yr}^{-1}$. These values are higher than those observed for the Ampelisca tenuicomis, $0.103 \mathrm{~g} \mathrm{AFDW} \mathrm{m}^{-2} \mathrm{yr}^{-1}$ (Sheader 1977 ). The calculation of the ratio between annual production and mean biomass $(P / B)$ is a good method to compare productivities of different species, populations and communities (Ansell et al. 1978). The $P / B$ ratio calculated for $P$. brasiliensis is close to those recorded for Talorchestia capensis $\left(2.25 \mathrm{yr}^{-1}\right.$; Van Senus \& MCLachlan 1986) and Parhyale basrensis (3.06 $\mathrm{yr}^{-1}$; Ali \& Salman 1987). The values found for the $P / B$ ratio together with a life span of between 1 and 1.75 yr recorded for $P$. brasiliensis corroborate the observations of Zaika (1973) and Robertson (1979) on the inverse relationship between these parameters. Zaika (1973) suggested that species with a $P / B$ ratio close: to $3.0 \mathrm{yr}^{-1}$ tend to have life expectancies between 1 and 2 yr

The high mortality rate, rapid growth rate and high $P / B$ ratio value found for Pseudorchestoidea brasiliensis as compared to published data may indicate a rolationship of these parameters with geographical regions, confirming the conclusions of Ansell el al. (1978). Those authors demonstrated that tropical species exhibit high mortality rates, rapid growth rates and a higher production per unit biomass compared to temperate species.
Acknowledgements. This paper represents the dissertation submitted by the first author to the Universidade Federal do Rio de Janeiro in partial fulfilment of the requirements for an M.Sc. degree in Ecology. We thank Dr R. S. Absalato, Dr P. J. P. Santos and 2 anonymous referees for critically reading the mariuscript. Thanks also to Drs Y. Wakabara and E. L. Bousfield for identifying the species studied, to Dr P. Paiva and Dr F. Fernandez for English language revision, to all participants in the field work, and to Drs M. Széchy and R. Martino for equipment facilities. This study was supported by Coordenacáo de Aperfeiçamento de Pessoal de Nivel Superior (CAPES) postgraduate research studentships.

\section{LITERATURE CITED}

Ali MH, Salman SD (1987) Growth and production of the amphipod Parhyale basrensis (Talitridae) in the Shatt alArab region. Mar Ecol Prog Ser 40:231-238

Ansell AD, McLusky DS, Strrling A, Trevallion A (1978) Production and energy flow in the macrobenthos of two sandy beaches in south west India. Proc R Soc Edinb $76 \mathrm{~B}$ $269-296$

Benke AC (1979) A modification of the Hynes method for estimating secondary production with particular significance for multivoltine populations. Limnol Oceanogr 24:168-171

Behbehani MJ, Croker RA (1982) Ecology of beach wrack in northern New England with special reference to Orchestia platensis. Estuar Coast Shelf Sci 15:611-620

Bousfield EL (1982) The amphipod superfamily Talitroidea in the northeastern Pacific region. I. Family Talitridae: systematics and distributional ecology. Natl Mus Nat Sci (Ott) Publ Biol Oceanogr 11:1-73

Bowers DE (1964) Natural history of two beach hoppers of the genus Orchestoidea (Crustacea: Amphipoda) with reference to their complemental distribution. Ecology 45: $677-696$

Carrasco FD, Arcos DF (1984) Life history and production of a cold temperate population of the sublittoral amphipod Ampelisca araucana. Mar Ecol Prog Ser 14:245-252

Craig PC (1971) An analysis of the concept of lunar orientation in Orchestoidea corniculata (Amphipoda). Anim Behav 19:368-374

Craig PC (1973a) Orientation of the sand beach amphipod Orchestoidea corniculata. Anim Behav 21:699-706

Craig PC (1973b) Behaviour and distribution of the sand beach amphipod Orchestoidea corniculata. Mar Biol 23: $101-109$

Crisp DJ (1984) Energy flow measurements. In: Holme NA McIntyre $A D$ (eds) Methods for the study of marine benthos. Blackwell Scientific Publications [IBP Handbook no. 16], Oxford, p 284-372

Duarte WE (1974) Orchestoidea tuberculata Nicolet, 1840 as an organism which disintegrates algae (Crustacea, Amphipoda, Talitridaej. Mus Nac His Nat Not Mens (Santiago) 19:3-9

Gayanilo FC. Jr, Soriano M, Pauly D (1988) A draft guide to the Compleat ELEFAN. ICLARM Software 2, International Center for Living Aquatic Resources Management, Manila

Griffiths CL. Stenton-Dozey JME, Koop K (1983) Kelp wrack and the flow of energy through a sandy beach ecosystem. In: McLachlan A, Erasmus T (eds) Sandy beaches as ecosystems. W. Junk, The Hague, p 547-556

Hamilton AL (1969) On estimating annual production. Limnol Oceanogr 14:771-782

Hastings $\mathrm{MH}$ (1981) The life cycle and productivity of an intertidal population of the amphipod Ampelisca brevi- 
cornis. Estuar Coast Shelf Sci 12:665-677

Hynes HBN, Coleman MH (1968) A simple method of assessing the annual production of stream benthos. Limnol Oceanogr 13:569--573

Klein G, Rachor E. Gerlach SA (1975) Dynamics and productivity of two populations of the benthic tube dwelling amphupod Ampelisca brevicornis (Costa) in Helgoland Bight. Ophelia 14:139-159

Maclntyre RJ (1963) The supralittoral fringe of New Zealand beaches. Trans R Soc NZ 88:89-103

Marques JC, Nogueira A (1991) Life cycle, dynamics, and production of Echinogammarus marinus [Leach (Amphipoda)] in the Mondego estuary (Portugal). Oceanol Acta $11: 213-223$

Marsden ID (1989) An assessment of seasonal adaptation in the beach hopper Talorchestia quoyana (Milne-Edwards). J Exp Mar Biol Ecol 129:203-218

Marsden ID (1991) Kelp-sandhopper interactions on a sand beach in New Zealand. II. Population dynamics of Talorchestia quoyana (Milne-Edwards). J Exp Mar Biol Ecol 152:75-90

Masselink G, Short AD (1993) The effect of tide range on beach morphodynamics and morphology: a conceptual beach model. J Coastal Res 9:785-800

McLachlan A (1980) The definition of sand beaches in relation to exposure: a simple rating system. S Afr J Zool 76 : $137-138$

McLachlan A, Wooldridge T, Dye AH (1981) The ecology of sand beaches in South Africa. S Afr J Zool 16:219-231

Menzie CA (1980) A note on the Hynes method of estimating secondary production. Limnol Oceanogr 25:770-773

Morino H (1978) Studies on the Tallitridae (Amphipoda, Crustacea) in Japan. IlI. Life history and breeding activity of Orchestia platensis Kroyer. Publ Seto Mar Biol Lab 24: $245-267$

Pauly D (1986) On improving operation and use of the ELEFAN programs. Part II. Improving the estimation of Lim. Fishbyte 4:18-20

Pauly D, Gaschutz G (1979) A simple method for fitting oscillating length growth data with a program for pocket calculators. Comm Meet In Counc Explor Sea (Demersal Fish Comm) G2424

Ricker WE (1975) Computation and interpretation of biological statistics of fish populations. Bull Fish Res Board Can 191:1-382

Robertson Al (1979) The relationship between annual production: biomass ratios and lifespans for marine macrobenthos. Oecologia 38:193-202

Ruffino ML (1991) Dinâmica populacional do camarāo Artemesia longinaris Bate, 1888 (Decapoda, Penaeidae) do sul do Brasil. MSc thesis, Depto Ogeanografia, University do Rio Grande, RS, Brazil

Sheader $M$ (1977) Production and population dynamics of

This article was presented by P. J. Wangersky (Senjor Editorial Advisor), Victoria, British Columbia, Canada
Ampelisca tenuicornis (Amphipoda) with notes on the biology of its parasite Sphaeronella longupes (Copepoda). J Mar Biol Ass UK 57:955-968

Short AD, Wright LD (1983) Physical variability of sandy beaches. In: McLachlan A, Erasmus T (eds) Sandy beaches as ecosystems. W. Junk, The Hague, p 133-144

Sparre P, Ursin E, Venema S (1989) Introduction to tropical fish stock assessment. Part I. FAO Fish. Tech Pap

Steele VJ (1981) The effect of photopenod on the reproductive cycle of Gammarus lawrencianus Bousfield. J Exp Mar Biol Ecol 53:1-7

Steele DH, Steele VJ (1975) The biology of Gammarus (Crustacea, Amphipoda) in the northwest Atlantic. XI. Comparison and discussion. Can J Zool 53:1116-1126

Urban HJ, Campos B (1994) Population dynamics of the bivalves Gari solida, Semele solida and Protothaca thaca from a small bay in Chile at $36^{\circ} \mathrm{S}$. Mar Ecol Prog Ser 115 93-102

Van Senus P (1988) Reproduction of the sandhopper Talorchestia capensis (Dana) (Amphipoda, Talitridae). Crustaceana 55:93-103

Van Senus P, McLachlan A (1986) Growth, production, and a partial energy budget for the amphipod Talorchestia capensis (Crustacea, Talitridae) in the Eastern Cape, South Africa. PSZN I: Mar Ecol 7(2):165-179

Veloso VG, Cardoso RS, Fonseca DB (1996) Spatiotemporal characterization of the intertidal macrofauna at Prainha beach (Recreio dos Bandeirantes), State of Rio de Janeiro. Oecologia Brasiliensis 3(in press)

Venables BJ (1981) Aspects of the population biology of a Venezuelan beach amphipod Talorchestia margaritae (Talitridae) including estimates of biomass and daily production and respiration rates. Crustaceana 41:271-285

Wildish DJ (1970) Polymorphism in Orchestia mediterranea A. Costa (Amphipoda: Talitridae). Crustaceana 19:113-118

Wildish DJ (1972) Post-embryonic growth and age in some littoral Orchestia (Amphipoda, Talitridae). Crustaceana Suppl 3:267-274

Wildish DJ (1979) Reproductive consequences of the terrestral habit in Orchestia (Crustacea: Amphipoda). Int J Invertebr Reprod 1:9-20

Wildish DJ (1982) Evolutionary ecology of reproduction in gammaridean Amphipoda. Int J Invertebr Reprod 5:1-19

Williams JA (1978) The annual pattern of reproduction of Talitrus saltator. J Zool 184:231-244

Williams JA (1983) Environmental regulation of the burrow depth distribution of the sand-beach Amphipod Talitrus saltator. Estuar Coast Shelf Sci 16:291-298

Williams JA (1985) The role of photoperiod in the initiation of breeding and brood development in the amphipod Talitrus saltator Montagu. J Exp Mar Biol Ecol 86:59-62

Zaika VE (1973) Specific production of aquatic invertebrates. John Wiley \& Sons, New York

Manuscript first received: Apri 10,1996

Revised version accepted: July 27, 1996 